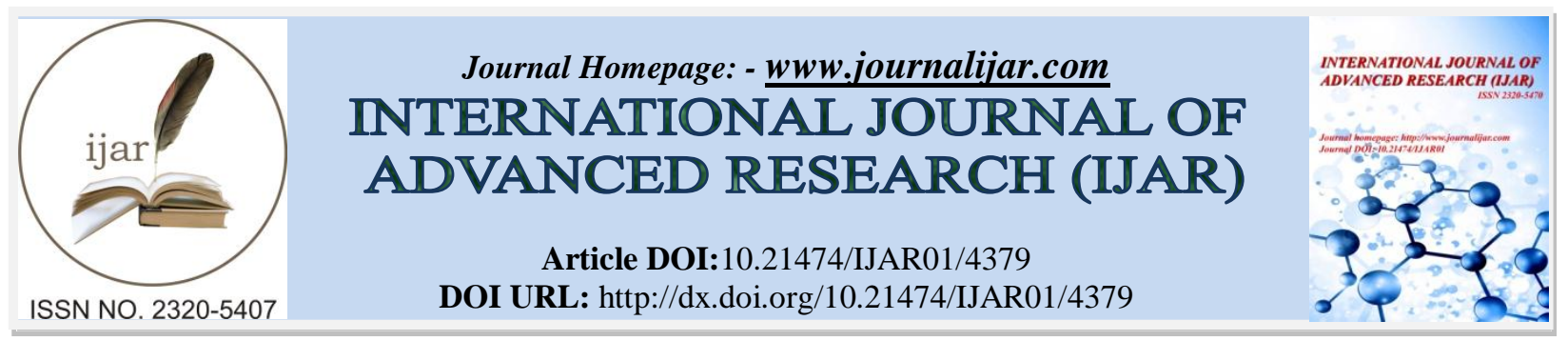

RESEARCH ARTICLE

\title{
STRATEGIC PLANNING PROCESS AND ITS EFFECTS ON EMPLOYEE PROCUREMENT IN ORGANISATION.
}

Okeke Raymond Njelita and Agu Dennis Eberechi.

1. Department Of Management, University Of Nigeria, Enugu Campus.

2. Department of Business Administration and Management Imo State Polytechnic, Umuagwo.

\section{Manuscript Info}

(..........................

Manuscript History

Received: 01 april 2017

Final Accepted: 03 june 2017

Published: june 2017

Key words:-

Strategic, planning, procurement, employee, organisation

\section{Abstract}

This work is on strategic planning process and its effects on employee procurement in AC Pharmaceuticals Ltd, Enugu, Nigeria. Successful organisations are those that have a strategic planning for obtaining the right number and the right kind of employees. The objectives of the study were to ascertain strategic planning features that bear on employee procurement and to determine the impact of strategic planning on employee procurement. The work concluded that organisation employs strategic planning process in employee procurement; strategic planning process ensures survival of organisation; it ensures procurement of the right number and right kind of employees; it exposes future demand pattern of employee procurement; it provides a guide to employee evaluation; and it sets training guide for employee. Therefore the work recommended that employee procurement process should base on wide consultation; it should be comprehensive; it should be systematic; it should be flexible to adapt to changing situations and organisation should monitor employee procurement process.

Copy Right, IJAR, 2017,. All rights reserved.

\section{Introduction:-}

In an increasingly dynamic, interdependent, and unpredictable world of business, competition is reshaping industries and leading them into uncharted territory. Where the only certainty is uncertainty- markets shift, technologies proliferate, competitors multiply and products become obsolete virtually overnight. Successful organisations are those that have laid down strategic planning process for procuring the right kind and number of employees that will be of assistance in manning organisations. As organisations are only as good as the people in them. It consists of recruiting, training, and developing people who can contribute to organized effort (Wheirich, Cannice and Koontz, 2010:156). Procurement results not only in the organisation's acceptance of the man but also in the man's acceptance of and satisfaction with his job and the organisation, demonstrating the willingness to be committed and aimed towards accomplishments of goals and standards. This can be determined by following up formal placement to verify supervisors satisfaction with the employee and the employee satisfaction with the job, department, supervisor and the organisation (Ikeagwu, in Imaga and Ewurum,1998:120).

Manager takes a preliminary look at possible future opportunities and knows where its organisation stands in the light of its strengths and weaknesses. Understanding what problems it has to solve and why and know what it can expect to gain. On the basis of which the manager visualises and predicts the kind and number of staff that will be 
required to achieve the targeted objectives. This is possible if the organisation does not recruit someone who although competent but technically is unlikely to work in harmonious relations with other staff, customers or suppliers or who is likely to upset the cohesiveness of work groups. What makes an organisation is the ability of its members to work with one another by sharing work, ideas and knowledge. Organisation that intends to compete through people must take the utmost care with how it chooses its members (Mullins, 2007:800).

Organisation relies on their employees to seek out customers and change competitive positions, prompting competition to intensify on a global scale (Wild and Wild, 2013:26). These new realities alter competitive positions and transform ways companies do business. In designing an environment for the effective performance of individuals working together in a group, a manager's task is to see that everyone understands the group's mission and objectives and the methods for attaining them. Selecting the right employees is important because manager's performance depend on the employee performance. Managers must establish an environment in which people can accomplish group goals with the least time, money, materials, and personal dissatisfaction or in which they can achieve as much as possible of a desired goal with available resources. Worthwhile employee procurement must not be a matter of sheer luck; it requires systematic and rational work, well organized and managed for results.

The old model that the top thinks and the lower acts has now given way to integrative thinking and acting at all levels. Managers and employees set strategies to harness the collective genius of the people in organisations (Dess, Lumpkin and Eisner, 2009:23). This is in a bid to cope with demands of global competition, customer expectations, and the need to respond quickly to environmental changes. Organisation and people need each other. The essence of organisation has shifted and will continue to shift from focusing on structure to capability. Employee loyalty is essential and expected. Hence prospective employees are screened for their ability to work in a group and with also senior management. Formal organisation is a coalition of individuals with a number of sub-coalitions. Organisation makes it possible for people to achieve those things they could not achieve individually (Akpala, 1990:48).

There is the compelling need to mould the efforts and decisions of different divisions, departments, managers and groups into a co-ordinated, compatible whole. When organisation's wide objectives are broken down into specific targets for each organisation's unit, lower level managers are held accountable for achieving them. Therefore there is little if any internal confusion over what to accomplish. The ideal situation is a team effort where each organisation's unit strives to produce results in its areas of responsibility that contribute to the achievement of organisation's performance targets and strategic vision, (Thompson and Strickland, 2003:7).

\section{Objectives of The Study:-}

1. To ascertain strategic planning features that bear on employee procurement.

2. To determine the impact of strategic planning on employee procurement.

\section{Concept Of Strategic Planning:-}

Strategic planning consists of analysis, decisions and actions an organisation undertakes in order to create and sustain competitive advantage (Dess et al., 2009:8). It entails three ongoing processes: analysis, decisions, and actions. Strategic management is concerned with the analysis of the internal and external environment of the organisation. External environment includes environmental scanning, environmental monitoring, competitive intelligence and environmental forecasting. Environmental scanning involves surveillance of a firm's external environment to predict environmental changes and detect changes already underway. Monitoring tracks the evolution of environmental trends, sequences of events or streams of activities. While competitive intelligence helps organisations define and understand their industry and identify rivals' strengths and weaknesses. Forecasting is predicting direction, scope, speed and intensity of changes in the environment. Internal environment involves structure- chain of command; culture- beliefs, expectations, values; and resources- asset, skills, competencies and knowledge. Managers make strategic decisions. These decisions broadly speaking address two basic questions: what industries are we to compete in? How are we to compete in those industries? The last is what action must be taken? This is because decision is of little use unless it is acted upon.

Again, strategic management is the continuous process of making present entrepreneurial "risk-taking" decision systematic and with the best possible knowledge of their futurity, organising systematically the efforts needed to carry out these decisions and measuring the results of these decisions against the expectations through organised systematic feedback (Drucker, 1977:115). It does not centre on future decision but on the futurity of present decision. This is because decision exists only in the present. The question that faces the strategist is not what an 
organisation should do tomorrow, but what it would do today to be ready for uncertain tomorrow. Strategic management is not all about what will happen in the future, but what futurity does organisation factor into their present thinking and doing, what time span do they have to consider, and how do they use the information to make a good decision now. It is a decision taken now that will impact on organisation both now and in the future.

According to Wheelen and Hunger (2009:9), strategic management is that set of managerial decisions and actions that determines the long-run performance of a corporation. It includes environmental scanning, strategic formulation, strategy implementation and evaluation and control. The study of strategic management therefore emphasizes the monitoring and evaluation of external opportunities and threats in the light of corporation's strengths and weaknesses.

\section{Features Of Strategic Planning That Bear On Procurement:- Comprehensiveness:-}

Procurement process is not only restricted to the department that presented the requisition. It involves all departments in the organisation. This is because activities of an employee do not only affect its department but the whole organisation. As organisation is a system. Organisation takes inventory of their staff to determine whether they are over staffed or not. In a case where there is over staffing, organisation resorts to downsizing. It takes to redeployment of staff from one department to the other if there is shortage in one department. Procurement is supported only if there is shortage of staff or where there is lack of qualified candidates within the organisation to occupy the vacancy. Where it is glaring that procurement is necessary the account department has to prove the financial capacity of the organisation to accommodate such endeavour. This also applies to other sections of the organisation whose the activities of the would-be employee will be affected. Coventry in Akpala, (1990:47), states that strategic management not only covers the whole organisation but every functional aspect of the organisation or firms' business. It also takes into account the full environment in which the organisation operates. Strategic management is directed towards overall organisational goal and objectives. It is a plan that recognises and takes into consideration every aspect of an organisation. It is an all inclusive plan and not just a single functional plan. It takes a deep analysis of external as well as internal environments of an organisation (Wilson,1993:18).

\section{Multiple Stakeholders:-}

Procurement in organisation involves multiple stakeholders in its process of crafting, formulating, analysing, implementing, executing, evaluating and controlling. Managers incorporate the opinions and suggestions of many individuals and groups who have something to do with the operations of the organisation. The stakeholders include stockholders, board of directors, management, employees, customers, suppliers', community and even governmental agencies (Lewis, 2002:38). Since the lead responsibility for crafting and executing procurement process falls on key managers, the chief strategic role of an organisation's boards is to exercise oversight and see that the process is done in a manner that benefits shareholders. It is a standard procedure for executives to brief board members on importance of the intended procurement. The manager submits his plans to the board for official approval. Top management functions is usually conducted by the CEO of an organisation in conjunction with the chief operating officers, or president, executive vice president, and vice presidents of divisions and functional areas and also work with and through other lower managers and other employees to achieve strategic objectives (Monks, and Minow, 2001:133).

\section{Adaptability:-}

Adaptability ensures the continuous relevance of employee towards achieving objectives. In an environment where technology proliferates, competition very high and products become obsolete within a very short time organisation can only be sure of survival if it has dynamic staff in its employment. Success arises from being different, and then being prepared to change again as situations changes. Technology, globalisation and the demand for customization, enhancements, speed, and cost containment are driving change. The ability to adjust to the environment ensures the survival of organisation. Strategic planning has now evolved to the point that its primary value is helping an organisation operate successfully in a dynamic and complex environment (Wheleen, and Hunger, 2007:9). This means that organisations develop flexibility to enable it shift from one dominant strategy to another. Strategic flexibility demands a long term commitment to the development and nurturing of critical resources. It also demands that the company become a learning organisation - an organisation skilled at creating, acquiring and transferring knowledge and at modifying its behaviour to reflect new knowledge and insight. Managers continually analyse the changes in the environment in order to create or modify strategic plans. To be competitive in the dynamic environments, organisations are becoming less bureaucratic and more flexible (Aderson, 2000:184). 


\begin{abstract}
Ongoing:-
Procurement criteria are continuously fine tuned to meet present day requirements. It is an ongoing, never ending process, not a start-stop event that once done, can be safely put aside for a while. Consequently, managers are obliged to re-evaluate recruitment strategy regularly, refining and recasting it as often and as much as needed to match the organisation's changing external and internal circumstances (Gluck, Kaufraon, and Walleck, 1982:9). Managers have an ever-present responsibility for detecting when new developments require a new employee and when they don't. Their job is to track progress, spot problems and issues early warning, monitor the winds of market and customer changes, and initiate adjustments as needed. This is when the task of evaluating performance and initiating corrective adjustment is both the end and beginning of the strategic planning cycle (Thompson and Strickland, 2003:20). Organisation is in constant planning and never ceases to plan. It is a survival strategy to keep abreast of developments in the environment. They seek information about the general as well as the industry environment in order to satisfy their customers.
\end{abstract}

\title{
Short-term As Well As Long-Term:-
}

Managers maintain both a vision for the future as well as a focus on its present operating needs for the organisation. They are in constant understanding of the manpower requirement of their organisations. This is because they are aware of the impact of environmental changes on their organisation performance. Maintaining a suitable manpower that meets the needs of the organisation now and in the future is critical to the survival of an organisation. Employees are the engine of every organisation. They utilize other organisation resources to assist in achieving objectives. Short and long term procurement plan ensures organisation readiness to withstand any environmental challenges. It also places organisation in a position to take advantage of the opportunities and circumvent threats. Any sustainable competitive advantage lies not in doggedly following a centrally managed five-year plan but in stringing together a series of strategic short-term thrust. Weihrich, et al., (2010:41) states that every short term plan must align with the long term plan of an organisation and any short term plan that does not agree with a long term plan of an organisation is a miss-direction. Short term plans are also used to adjust organisation long term plan to sudden technological, social, economic and governmental changes. This is done to meet the immediate demand of the environment.

\section{Systematic:-}

Procurement of employee takes a systematic process. It follows specified sequence of well defined sets of steps and also involves various well planned stages i.e, all steps are kilter related and one step leads to another. First it starts with forecast of the manager attempts to ascertain the supply of and demand for various types of human resources. The primary goal is to predict area within the organisation where there will be future labour shortage or surpluses. And the decision of organisation's management to embark on procurement exercise to job analysis to job description to job specification to job advert to job interview to selection and to placement. Procurement follows a well planned procedure. Coventry (1970:86), asserts that strategic planning is a systematic assessment of a most comprehensive nature leading to the realistic mapping of long term objectives, strategic and operational plans. It is characterized by carefully designed procedures. It explains manager aspiration for the organisation and its business, providing a panoramic view of where they are going and giving specifics about its future business plans. It spells out long-term business purpose and mould organisational identity (Thompson and Strickland, 200:4).

\section{Targeted:-}

Procurement targets a specific kind and number of employees. It states the skills set that are expected from employees. This is important because manager's performance depends majorly on the subordinates. Therefore the time to screen out undesirables is before they are at the door, not after. Again it is important because it is costly to recruit and hire only to be fired the next moment. From pool of applicants, selection of best candidates for the job is done. This usually means whittling down the applicant pool by using the screening tools like tests, assessment centres, and background and reference check- plan that is expected to solve, create and deal with a specific situation. It focuses on a particular buyer group, segment of product line or geographic market. Strategic planning rests on the premise that the firm is thus able to serve its narrow strategic target more effectively or efficiently than competitors who compete more broadly. It is built upon the ability to foresee future results of present initiatives and its established targets (Dessler,2005:113).

\section{Consequential:-}

Procurement is a process that takes substantial amount of money and commitment from organisation's management. The processes involved in procurement are cost to the organisation. It demands a great deal of commitment from 
people at all levels of organisation, and requires an extensive knowledge of the environment, market and competitors. All these demand a great deal from the organisation.

\section{Impact Of Strategic Planning On Employee Procurement:- Recruiting the Right Kind and Number:-}

The first step in procurement process is forecasting supply of and demand for various types and number of human resources. Strategic planning process assists in the recruitment of the right kind and number of employees into the organisation. They are the intellectual property of the firm. This is based on ideas and concepts- not machinery and processes. Human beings are the most valued resource of organisation. The strength of every organisation is dependent on capability and capacity of its human resource. They use materials, money and capital to achieve objectives. As we move on in this $21^{\text {st }}$ century, we are entering an era of constant change, Becoming - and remaining- the winner, will require an ever increasing ability to make the right decisions and to execute those decisions more effectively than competitors. This can only be achieved by organisation if it has the right set of employees in its employment. Success stems from knowledgeably applying a combination of available resources to needs of each individual situation. This implies that individuals have to increasingly and continuously learn and relearn value adding knowledge and skill. Human capital is the collective skills and knowledge of the firm's workforce. This is what creates value and enhance the value of the firm (Iyer, 2009:14).

\section{Creates Employee Loyalty and Retention:-}

Good and conducive organisational environment creates employees delight. Delighted employees remain loyal and committed to their organisation. Proper employee procurement planning matches employee to his job and the job to him. This is the factor that creates retention and commitment. Managers understand the main influences on behaviour in work organisations and the nature of people-organisation relationship. To do this involve consideration of interactions among the formal structure, the tasks to be undertaken, the technology employed and methods of carrying out work, the process of management and the external environment. It also reconciles the interest of employees with organisational interest. Where the needs of the individual and the demands of the organisation are incompatible, this can result in frustration and conflict. Strategic management integrates the individual and the organisation, and to provide a working environment which permits satisfaction of individual needs as well as the attainment of organisational goal (Mullins,2009:28).

\section{Guide to Performance Evaluation:-}

Strategic planning process sets the parameter for assessing performance of employees in line with stated objectives. These objectives are in the areas where activities critical to the operation and success of the organisation for example in marketing, innovation, productivity, financial resources, profitability, managerial performance, worker performance and public responsibility (Drucker,1977:286). A performance evaluation compares each employee's actual performance standards. Managers use job analysis to determine the job's specific activities and performance standards. At intervals organisation all ways likes finding how far it is achieving its stated objectives. Specific recommendations for improving productivity of individuals and suggestions on what individuals are expected to be doing to make realisation of objectives possible. Managers plot their future course through planning. But even the most careful prepared plan is no guarantee of success. Hence managers need to take definite steps to keep things headed in the right direction. Evaluation complement planning by introducing corrective action as the plan are being implemented (Akpala,1990:121).

\section{Integrates Employees:-}

One of the most difficult and frustrating challenges to management is integration of employee into an organisation. This involves employee being part and parcel of his organisation. It means sharing work, knowledge, ideas and sharing common objective. Strategic planning is concerned with attempts to effect a reasonable reconciliation of individual and organisational objectives and with the attitudes of members of the organisation. The plan states from the beginning what the job, position, remuneration, and the authority of the employee would be. It also expresses the parity of the authority and responsibility of the employees and its relationship within the structure of the organisation. This is enable employee to be fully integrated in the organisation. Measures developed to evaluate integration include morale surveys, absenteeism, tardiness and turnover. Also considered are the number of grievances obtained by comparing surveys of opinions and attitudes on various subjects of interest and between departments (Ikeagwu, 1998:122). 


\section{Extensive Communication/Consultation:-}

In setting or forming a strategic vision, objectives, crafting, implementing and executing strategic plan and evaluating performance in most cases involves almost all organisational members. The involvement of employees in planning and execution of strategic planning instil spirit of recognition for their contributions which spurs them to higher productivity and commitment. Every organisational member is fully aware of the intent of management. They also know what they are expected to do. This is because employees and managers throughout the organisation strive towards common goals and objectives (Mintzberg, Bruce and Joseph, 1998:96). By specifying desired result, it becomes much easier to move forward. Otherwise if the lower cadre knows not what the firm is striving to accomplish and have no idea of what to work towards; and how their work contributes to organisational objectives, the whole exercise will be a waste. Communication flows from top to the bottom and from bottom to the top and also horizontally. To ensure that every member of the organisation be fully aware of the developments in the organisation (Thompson and Strickland, 2004:20).

\section{Training/Development:-}

Increase of skill through training is the function of development of personnel. This is set out from strategic planning stage. The kind of training that is required for development of the employee is well stated even before the employee is recruited. Training is necessary for proper job performance and it is an activity of great importance. It will continue to grow because of the demand of new technology and automation. This provide the training to ensure that employee have the knowledge the skills needed to accomplish their task, concepts and technique for developing more capable employees and organisation. The aim is to improve enhance the future performance of the organisation. Besides training and development employees must be told what they are expected to do and how they are expected to do it. This is important in order not to allow employees work according to their own dictate. However training remains waste if the employee lacks the ability or motivation to benefit from it (Dessler, 2005:270).

\section{Ensures Survival of Organisation:-}

Strategic planning process assists in procurement of employees that will contribute highly for the survival of organisation. This helps organisation to be ready for present and uncertain tomorrow. It ensures the long run survival of organisation. Survival of organisation is at the heart of strategic management. It states what that has to be present in an organisation to enable to be ready both now and in the future; by stating the vision, mission, objectives and the general future direction of the organisation. It also maintains the strategies and facts required to achieve them. Strategic planning is primarily to ensure the survival of organisation and this is of course what differentiates it from other plans (Drucker, 1977:118).

\section{Exposes Future Demand Pattern:-}

Strategic planning is based on extensive study and investigation which more often than not exposes future demand pattern. This prompts organisation to move for procurement of employees to meet the changes in demand. Organisation can not afford to be taken unawares. It is made to be prepared to take up new challenges associated with changing times, Being in touch with the pattern of demand ensures the survival of organisations. Where there is change in the demand, organisations embarks on acquiring or retrenching or retraining of employees. This is because modern facilities and techniques are required to meet the demand of current development in their industry. This ensures continued existence of organisation. It makes organisations being ahead of their rivals and reduces the chances of it not going into obsolesce. Achieving competitive advantage is dependent on the ability of an organisation to satisfy the ever-changing needs of the consumers or even surpass it. Customers' satisfaction is the purpose of business. This is because survival and failure of organisation is dependent on the abilities and capabilities of organisations to meet consumer demand (Arora, 2008:129).

\section{Research Methodology:-}

The study was carried out at AC Pharmaceuticals Ltd, Enugu in Enugu State of Nigeria. The study was a survey research and the instrument used for data collection was questionnaire structured in line with 5 points likert scale. A sample size of 398 respondents was obtained from a population of 896 respondents. The respondents were people from various organisational levels who were involved in the formulation, implementation and execution of strategic planning. The completed questionnaire was collected, coded and subsequently analysed using percentages and descriptive statistics. 
Table 3:1:- Questionnaire Frequency Distribution

\begin{tabular}{|c|c|c|c|c|c|}
\hline e & SA & A & UD & D & SD \\
\hline $\begin{array}{l}\text { Procurement provides the right number and kind of employee to } \\
\text { organization }\end{array}$ & 117 & 237 & 6 & 16 & - \\
\hline It creates employee loyalty and retention in an organization & 127 & 229 & - & 17 & 3 \\
\hline $\begin{array}{l}\begin{array}{l}\text { Strategic planning process provides a guide to employee } \\
\text { evaluation }\end{array} \\
\end{array}$ & 189 & 168 & - & 9 & 10 \\
\hline $\begin{array}{llllll}\begin{array}{l}\text { Strategic planning process } \\
\text { organization }\end{array} & \text { integrates employee into his } \\
\end{array}$ & 152 & 221 & - & 3 & - \\
\hline Strategic planning process involves train and develop employee & 76 & 210 & 13 & 57 & 20 \\
\hline Procurement ensures survival of organization & 87 & 262 & 3 & 24 & - \\
\hline $\begin{array}{l}\text { Strategic planning process exposes future demand pattern as } \\
\text { environment changes }\end{array}$ & 216 & 147 & - & 9 & 4 \\
\hline $\begin{array}{l}\text { Strategic planning process creates wide consultation and } \\
\text { communication within the organization in procurement process }\end{array}$ & 51 & 72 & 37 & 149 & 67 \\
\hline
\end{tabular}

\section{Source: field survey}

Table 3.2:- Descriptive Statistics

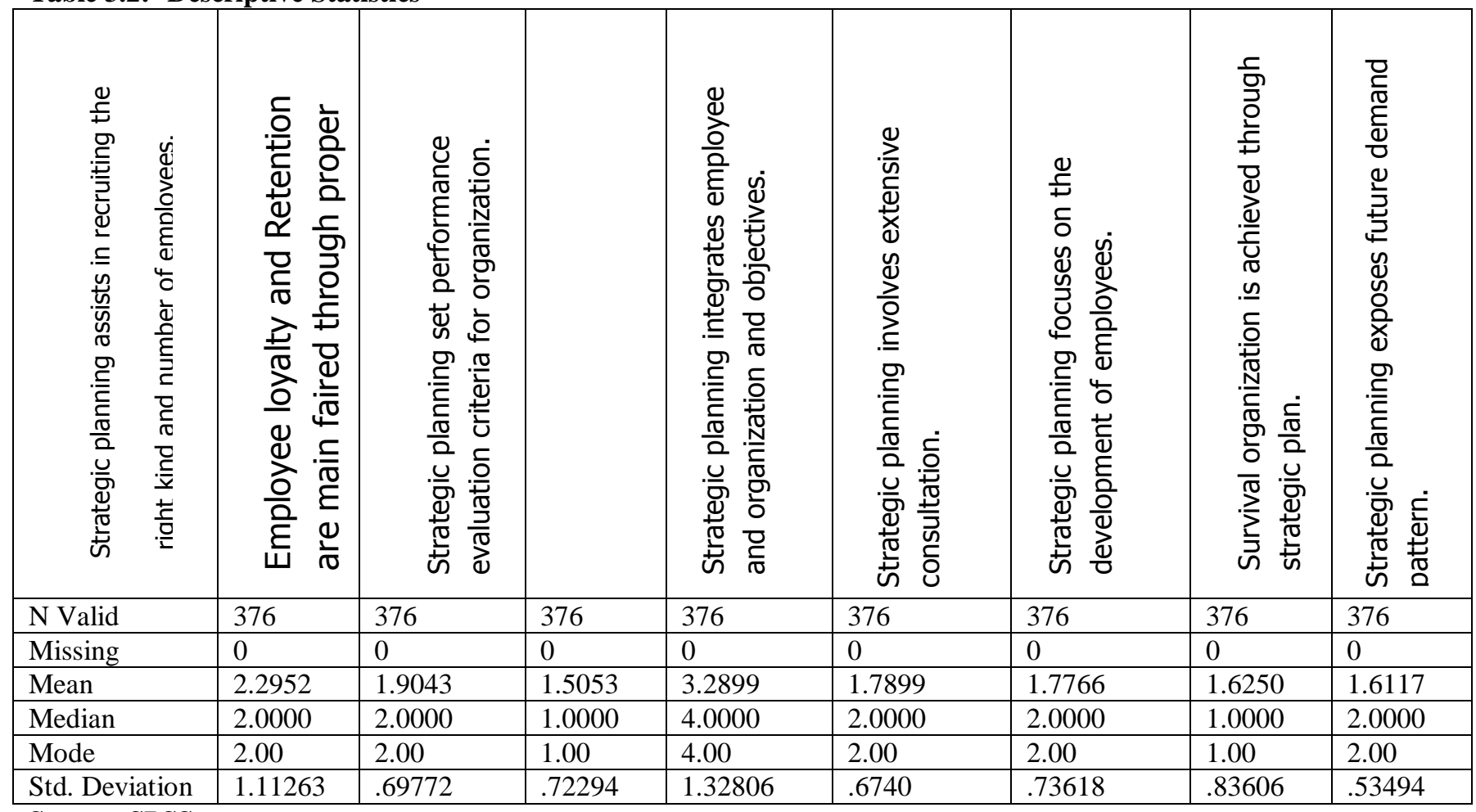

Source: SPSS

The analysis from descriptive statistics table shows a significant impact of strategic planning process on employee procurement in organisation. It further reveals that there is positive relationship between strategic planning and employee procurement. For optimal performance of employee it is important that organisation plans ahead of time to be read for environmental unforeseen challenges.

\section{Conclusion:-}

Strategic planning process impacts on procurement of the right number and right kind of employees.

Strategic planning process of employee procurement ensures survival of organisation

It exposes future demand pattern.

It involves a continuous process and not a one-stop plan.

It ensures integration of employee in organisation. 


\section{Recommendations:-}

1. Employee procurement process should be based on wide consultation.

2. Employee procurement process should be comprehensive enough to include all organisation functions.

3. Procurement should be systematic i.e, each step in the process should be interrelated - one step leading to the other.

4. Strategic planning process of employee procurement should be flexible enough to be able to adjust to changes in the environment.

5. Organisation should monitor implementation of strategic planning process on employee procurement.

\section{References:-}

1. Abel, G. (1999), Competing Today Nigeria While Preparing for Tomorrow, Sloan Management review 40(3).

2. Akpala, A. (1990), Element of Management: A Nigeria ,Perspective, Enugu Sunshine Press.

3. Andersen, J. (2000), "Strategic Planning Autonomous Action and Corporate Performance"Long Range Planning.

4. Campbell, Andrew and Nash (1993), A Sense of Mission: Defining Direction for the large corporation.

5. Gluck F. et al. (1982) The Four Phases of Strategic Management Journal of Business Strategy.

6. Collins, J. (1999), Turning Goals into Results: The Power of Catalytic Mechanism, Harvard Business review 77(4).

7. Denton, K. (1995), Creating a System for Continuous Improvement Business Horizons 38(1).

8. Dess, G. et al. (2009), Strategic Management, Text and Cases, New York, McGraw Hill.

9. Drucker, P. (1977), Management, Task, Responsibilities, Practices, Abridged Version, New York Harper and Row.

10. Hamel, G. (2000), Leading the Revolution. Boston Harvard Business School Press.

11. Hamel, G. (1996), Strategy as Revolution Business review 74(, 4)

12. Lipton, M. (1996), Demystifying the Development of an Organisational Vision, Sloan Management Review.

13. Lynch, R. (2003), Corporate Strategy, Financial Times Prentice Hall.

14. McTavish, R. (1995), One More Time: What Business Are You in. Long Range Planning 28(2).

15. Mintzbeg. H. (1999), Crafting Strategy, Harvard business review 65(4).

16. Mintzberg, H. (2004), Leadership and Management Development Academy of Management Executives 18(3).

17. Mintzberg, H. et al. (1998), Strategy Safari: A Guide Tour through the Wilds of Strategic Management, New York, Free press.

18. Monks, R. and Minow, W. (2001), Corporate Governance, Malden, MA: Blackwell.

19. Mullins, L (2007), Management and Organisational Behaviour, Delhi, Pearson.

20. Thompson and Strickland (2003), Strategic Management, New York, McGraw Hill.

21. Wheleen, G. and Hunger, J. (2009), Strategic Management and Business Policy, New York, Pearson.

22. Wilson, I. (1992), Realising the Power of Strategic Vision, Long Range Planning 25(5)

23. Wild, J. and Wild, L. (2013), International Business, London, Pearson Publishers.

24. Noe-Hollenback-Gerhart-Wright (2008), Human Resource Management: Gaining a Competitive Advantage, New-York, McGraw Hill. 